\title{
Performan, Karakteristik Fisik dan Kimia Daging Kambing Lokal Jantan Dengan Pemberian Pakan Kulit Buah Kakao Fermentasi
}

\section{(Performance, Physical and Chemical Characteristics of Local Goat Meat Feed on Fermented Cocoa Peel (Theobroma cacao L))}

\author{
Bulkaini, Djoko Kisworo, dan Mastur \\ Fakultas Peternakan Universitas Mataram, Nusa Tenggara Barat \\ Email : djokokisworo@unram.ac.id
}

Diterima : 30 Oktober 2019/Disetujui : 26 Nopember 2019

\begin{abstract}
ABSTRAK
Penelitian ini bertujuan untuk mengoptimalkan pemanfaatan kulit buah kakao (KBK) sebagai pakan ternak kambing dalam rangka meningkatkan kualitas daging. Penelitian dilaksanakan selama 2 bulan di Laboratorium Teaching Farm Fakultas Peternakan Universitas Mataram. Materi yang digunakan adalah 9 ekor kambing lokal jantan umur 9-12 bulan dengan berat ratarata 18,67 $\pm 1,53 \mathrm{~kg}$. Kambing dibagi secara acak menjadi 3 perlakuan dan 3 ulangan yaitu perlakuan P1: 30\% KBK fermentasi tanpa fermentor, jerami jagung dan dedak (KBKFTF); $\mathrm{P} 2=30 \% \mathrm{KBK}$ fermentasi dengan fermentor Bioplus, jerami jagung dan dedak (KBKFbioplus) dan $\mathrm{P} 3=30 \%$ KBK fermentasi dengan souse burger pakan, jerami jagung dan dedak (KBKFSBP). Hasil Analisa Varian menunjukkan bahwa jenis fermentor berpengaruh nyata $(\mathrm{P}<0,05)$ terhadap pertambahan bobot badan harian $(\mathrm{PBBh})$, konsumsi pakan dan keempukan daging kambing, sedangkan terhadap daya ikat air (DIA), susut masak, $\mathrm{pH}$ dan komposisi kimia daging tidak berpengaruh nyata $(\mathrm{P}>0,05)$. Kambing pada $\mathrm{P} 2$ memberikan $\mathrm{PBBh}$ sebesar $58,67 \pm 21,590 \mathrm{~g} /$ ekor/hari dan berbeda nyata $(\mathrm{P}>0,05)$ dengan $\mathrm{PBBh}$ kambing pada $\mathrm{P} 1(49,75 \pm 18,557 \mathrm{~g} / \mathrm{ekor} / \mathrm{hari})$ dan P3 (50,35 $\pm 19,606 \mathrm{~g} /$ ekor/hari). Keempukan daging pada $\mathrm{P} 2\left(2,04 \pm 0,50 \mathrm{~kg} / \mathrm{cm}^{2}\right)$ berbeda nyata $(\mathrm{P}<0.05)$ dengan keempukan daging pada $\mathrm{P} 1(1,97 \pm 0,58$ $\left.\mathrm{kg} / \mathrm{cm}^{2}\right)$ dan $\mathrm{P} 3\left(1,74 \pm 1,26 \mathrm{~kg} / \mathrm{cm}^{2}\right)$, sedangkan komposisi kimia daging tidak berbeda nyata $(\mathrm{P}>0,05)$ diantara semua perlakuan.
\end{abstract}

Kata kunci : Performan, Kulit Kakao Fermentasi, Karakteristik Fisik Dan Kimia Daging

\begin{abstract}
The study aims to optimize the use of cocoa peel as goat feed in order to improve meat quality. The study was conducted in 2 months at the Teaching Farm Laboratory, Faculty of Animal Husbandry, University of Mataram. The material used were 9 male local goats aged 9-12 months with an average body weight of $18.67 \pm 1.53 \mathrm{~kg}$. The goats were randomly divided into 3 group of treatments and 3 replications, namely the $\mathrm{P} 1=30 \%$ fermented cocoa peel without Bioplus fermenters + corn stak and rice bran (CPHFWF); P $2=30 \%$ fermented cocoa peel with Bioplus fermentor + corn stak and rice bran (CPHFbioplus) and P3 $=30 \%$ fermented cocoa peel with souse burger feed + corn stak and rice bran (CPHFSBF). Analysis of variant show that the type of fermentor has a significant effect $(\mathrm{P}<0.05)$ on daily gain, feed consumption and tenderness of goat meat. while the water holding capacity (WHC), cooking losses, $\mathrm{pH}$ and chemical composition of meat have no significant effect $(\mathrm{P}>0.05)$. Goats in $\mathrm{P} 2$ give daily gain of $58.67 \pm 21.590 \mathrm{~g} /$ day and was significantly different $(\mathrm{P}>0.05)$ from goat daily gain in P1 (49.75 $\pm 18.557 \mathrm{~g} /$ day) and P3 (50.35 $\pm 19.606 \mathrm{~g} /$ day). Meat tenderness of $\mathrm{P} 2(2.04 \pm 0.50 \mathrm{~kg} / \mathrm{cm} 2)$ was significantly different $(\mathrm{P}<0.05)$ to $\mathrm{P} 1(1.97 \pm 0.58 \mathrm{~kg} / \mathrm{cm} 2)$ and $\mathrm{P} 3(1.74 \pm 1.26 \mathrm{~kg} / \mathrm{cm} 2)$. while the chemical composition of meat was not significantly different $(\mathrm{P}>0.05)$ among all treatments.
\end{abstract}

Keywords: Fermented Cocoa Peel, Physical and Chemical Characteristics, Local Goat's Meat 


\section{PENDAHULUAN}

Kulit buah kakao (KBK) merupakan salah satu limbah perkebunan yang memiliki potensi yang besar untuk dijadikan pakan alternatif ternak ruminansia besar (sapi) dan ruminasia kecil seperti domba/kambing (Kamilidin dkk., 2012). NTB dalam angka menunjukkan bahwa produksi kakao mencapai 2.101,90 ton pertahun dengan jumlah kulit buah kakao sekitar 70\% (1.470,7 ton). Penggunaan KBK untuk pakan ternak kambing bisa mencapai $15 \%$ dari total ransum, sehingga pemanfaatan KBK dapat mengantisipasi masalah kekurangan pakan dan menghemat tenaga kerja dalam penyediaan pakan hijauan. KBK sebelum digunakan sebagai pakan ternak perlu difermentasi untuk menurunkan kadar lignin yang sulit dicerna oleh hewan dan untuk meningkatkan kadar protein dari 6-8 \% menjadi 12-15\% (Anas dkk., 2011). Pemberian KBK yang telah difermentasi pada ternak kambing dapat meningkatkan berat badan lebih dari 50 g/ekor/hari. Suparjo dkk. (2011), menyatakan bahwa kambing lokal jantan yang diberi pakan KBK terfermentasi sampai dengan 30\% dapat memberikan PBBh sebesar $101,79 \pm 1,79 \mathrm{~g} / \mathrm{ekor} / \mathrm{hari}$, sedangkan tanpa KBK fermentasi hanya mencapai $58,95 \pm 3,09 \mathrm{~g} / \mathrm{ekor} / \mathrm{hari}$. Dalam proses fermentasi faktor yang harus diperhatikan adalah jenis fermentor yang digunakan yaitu fermentor yang mudah didapat dan terjangkau oleh daya beli masyarakat. Beberapa jenis fermentor yang telah digunakan dengan hasil yang bervariasi antara lain: kombinasi EM4 dengan Urea (Anas dkk., 2011), biofit (Kamilidin dkk., 2012), Aspergillus oryzae, Kapang jenis $P$. chrysosporium (Laconi, 1998, Murni dkk., 2012) yang dapat menurunkan kandungan lignin sebesar 18,36\%, Aspergillus Niger (Priyono, 2009), Trichoderma sp, yang dapat meningkatkan kadar protein sebesar $24 \%$. Koruria rosea dapat meningkatkan kadar asam amino lysine 3,46\%, histidine
0,94\% dan kadar methionin sebesar 0,69\% (Kurniansyah dkk., 2011). Dari beberapa jensis fermentor yang telah diuji penggunaannya terhadap tingkat pertumbuhan kambing, perlu mengkaji jenis fermentor lain yang tersedia dipasaran seperti bioplus dan SBP (Souse Burger Pakan). Bioplus sebagai fermentor dalam proses fermentasi mampu meningkatkan kandungan protein $\mathrm{KBK}$ fermentasi dari 7,38\% menjadi 10,21\% (Karda dkk., 2014). Sourse burger pakan merupakan konsentrat yang digunakan sebagai pakan penguat, sumber protein, energi, mineral bagi ternak rumenansia (Kamilidin dkk., 2012). Penggunaan SBP dapat meningkatkan $\mathrm{PBBh}$ ruminansia, meningkatkan persentase karkas dan kualitas daging. Herman (1984), menyatakan bahwa persentase daging kambing kacang bisa mencapai 60\% sedangkan tulangnya mencapai $30 \%$. Menurut Wardojo (1993) bahwa daging dalam karkas kambing bisa mencapai $75 \%$. Hasnudi (2006) menyatakan bahwa kambing kacang jantan yang digemukkan dengan KBK fermentasi menghasilkan daging sebesar $65,6 \%$ dari berat potong dengan tulang sebesar 34,4\%. Bulkaini (1985), menyatakan bahwa kambing kacang muda kondisi gemuk yang dipelihara dengan pakan apa adanya menghasilkan daging sebesar $31,43 \pm 1,25 \%$ dari berat karkas dengan tulang sebesar $10,90 \pm 0,75 \%$.

Bioplus merupakan produk campuran mikroorganisme yang berbentuk serbuk kering dan telah diuji coba penggunaannya dalam ransum ternak kambing Madura dengan dosis pemberian 500 g/ekor menunjukkan pertambahan bobot badan (PBB) meningkat dari 55 menjadi 61 g/ekor/hari (Ngadiyono dan Baliarti, 2001), sedangkan pada ternak domba dengan pemberian 150 g/ekor menunjukkan bahwa serat tercerna meningkat dari 104 menjadi $117 \mathrm{~g} /$ hari. Pemberian dalam bentuk cair dapat juga dilakukan pada ternak kambing dengan 
dosis $5 \mathrm{ml} /$ ekor/hari (Parwati dkk., 1999). Pada ternak domba diberikan dalam bentuk serbuk dengan dosis 100-150 g/ekor, sedangkan pada ternak kambing diberikan $200-250 \mathrm{~g} /$ ekor tergantung pada bobot kambing (Prihardono, 2001, Ngadiyono dan Baliarti 2001).

\section{MATERI DAN METODE}

Materi penelitian yang digunakan adalah 9 ekor kambing lokal jantan umur 9-12 bulan dengan berat rata-rata $18,67 \pm 1,53 \mathrm{~kg}$, dibagi secara acak menjadi 3 perlakuan dan 3 ulangan yaitu perlakuan P1: $30 \%$ KBK fermentasi tanpa fermentor+jerami jagung dan dedak (KBKFTF); $\mathrm{P} 2=30 \% \mathrm{KBK}$ fermentasi dengan fermentor Bioplus+jerami jagung dan dedak (KBKFbioplus) dan P3=30\% KBK fermentasi dengan souse burger pakan dicampur jerami jagung dan dedak (KBKFSBP). Pengukuran PBBH, konsumsi pakan dan efisiensi pakan dilakukan pengamatan secara langsung. Pengukuran nilai $\mathrm{pH}$ dengan Metode
Ockerman (Sofiana, 2012). Daya ikat air (DIA) diuji dengan metode penekanan sesuai petunjuk Hamm (Soeparno, 2009). Susut masak dihitung berdasarkan selisih antara berat daging sebelum dimasak dan berat setelah dimasak dibagi dengan berat berat sebelum dimasak dikalikan 100\% (Komansilan, 2015). Daya putus daging diuji dengan metode shear press, modifikasi metode Warner-Bratzler (Soeparno, 2009). Data hasil penelitian dianalisis dengan menggunakan analysis of variance (ANOVA) berdasarkan Rancangan Acak Lengkap Pola searah dan dilanjutkan dengan uji Jarak Ganda Duncan New Multiple Range Test (Steel and Torrie, 2010).

\section{HASIL DAN PEMBAHASAN Pertambahan bobot badan harian (PBBh)}

Rata-rata $\mathrm{PBBh}$, konsumsi pakan dan efiensi penggunan pakan disajikan pada tabel 1 .

Tabel 1. Rata - rata pertambahan bobot badan, konsumsi pakan dan konversi pakan

\begin{tabular}{lcccc}
\hline \multicolumn{4}{c}{ Peubah } & \multicolumn{4}{c}{ Perlakuan } \\
\hline & P1 (KBKFTF) & P2(KBKFBioplus) & P3 (KBKFSBP) & P \\
\hline Bobot Akhir (kg) & $21,30 \pm 1,100$ & $22,3 \pm 1,100$ & $21,00 \pm 1,300$ & NS \\
PBBh (g/ekor/hari) & $49,75 \pm 18,557^{\mathrm{b}}$ & $58,67 \pm 21,590^{\mathrm{a}}$ & $50,34 \pm 19,606^{\mathrm{b}}$ & $*$ \\
Konsumsi pakan (g/ekor/hari) & $316,12 \pm 6,44^{\mathrm{a}}$ & $347,38 \pm 54,24^{\mathrm{a}}$ & $285,67 \pm 4,28^{\mathrm{b}}$ & $*$ \\
Konversi pakan & $6,35 \pm 0,05$ & $5,92 \pm 0,03$ & $5,67 \pm 0,05$ & NS \\
\hline
\end{tabular}

Keterangan : * = Berbeda nyata $(\mathrm{P}<0,05)$ dan $\mathrm{NS}=$ Non Signifikans

Hasil analisis varian menunujukkan bahwa jenis fermentor berpengaruh nyata $(\mathrm{P}<0,05)$ terhadap $\mathrm{PBBh}$ kambing lokal jantan yang digemukkan secara feddloting. Hal ini membuktikan bahwa keseimbangan gizi dalam ransum memberikan andil yang cukup signifikan terhadap penampilan produksi ternak. PBBh kambing lokal jantan tertinggi $(58,67 \mathrm{~g} / \mathrm{ekor} / \mathrm{hari})$ dicapai pada perlakuan P2(KBKFBioplus dan berbeda nyata $(\mathrm{P}<0,05)$ dengan perlakuan P1(49,75 g/ekor/hari) dan P3 (50,34 g/ekor/hari). Perbedaan ini disebabkan oleh oleh tingkat konsumsi pakan yang berbeda pula, selain itu juga dapat dipengaruhi oleh kualitas dan kuantitas pakan. Hal ini sesuai dengan pendapat Soeparno (2005) bahwa PBB sangat dipengaruhi oleh kualitas dan kuantitas pakan, artinya bahwa pertambahan bobot badan ternak sebanding dengan kualitas pakan yang dikonsumsi.

Tercapainya pertumbuhan yang lebih tinggi pada perlakuan P2 (KBKFBioplus) disebabkan oleh tercapainya keseimbangan ekosistem di dalam rumen sebagai akibat adanya keserasian nutrien penyusun ransum yang menunjang terjadinya hubungan yang sinergis antara mikroba di dalam rumen. 
Hal ini mempunyai implikasi terhadap kecernaan pakan yang lebih tinggi sehingga ternak mendapat pasokan nutrien lebih tinggi dan pada akhirnya pertumbuhan ternak menjadi lebih tinggi. Lebih rendahnya PBBh pada P1(KBKFTF) dan P3(KBKFSBP) kemungkinan disebabkan oleh terlalu banyaknya amoniak $\left(\mathrm{NH}_{3}\right)$ yang terbentuk di dalam rumen sehingga ekosistem rumen terganggu, dan pada akhirnya pertumbuhan ternak menjadi tidak optimal. PBBh yang rendah dapat juga disebabkan oleh ketersediaan nutrien yang dapat dikonversi menjadi daging masih kurang (Suparman dkk., 2016). PBBh kambing lokal jantan dengan pada perlakuan P2 (KBKFBioplus) lebih rendah jika dibandingkan dengan hasil penelitian Ngadiyono dan Baliarti (2001) yaitu PBBh kambing lokal jantan bisa mencapai $0,61 \mathrm{~g} / \mathrm{ekor} / \mathrm{hari}$, juga lebih rendah juga dengan hasil penelitian (Kamilidin, dkk.,2012) yaitu domba yang diberi pakan mengandung $40 \%$ dan $20 \%$ KBK fermentasi memberikan PBBh $128,57 \mathrm{~g} / \mathrm{ekor} /$ hari dan 83,33 g/ekor/hari. Perbedaan $\mathrm{PBBh}$ ini kemungkinan disebabkan karena faktor perbedaan suhu lingkungan dan faktor jenis pakan tambahan yang digunakan. Hal ini dipertegas lagi oleh Abadi dkk. (2015), bahwa pertumbuhan akan berjalan dengan baik tergantung faktor-faktor penunjangnya seperti lingkungan, genetik, dan tata laksana pemeliharaannya.

\section{Konsumsi pakan}

Hasil analisis varian menunujukkan bahwa jenis fermentor berpengaruh nyata $(\mathrm{P}<0,05)$ terhadap konsumsi pakan kambing lokal jantan yang digemukkan secara feddloting. Hal tersebut mencerminkan bahwa KBK fermentasi dengan fermentor yang berbeda dalam ransum dapat mempengaruhin selera makan ternak, sehingga tingkat konsumsi pakan berbeda. Konsumsi ransum pada dasarnya ditujukan untuk memenuhi kebutuhan energi ternak, sehingga ternak akan berhenti makan apabila ternak merasa tercukupi kebutuhan energinya. Pada tabel 1 di atas nilai konsumsi bahan kering berkisar 285,67-347,38 g/ekor/hari. Pada perlakuan P2 (KBKFBioplus) menunjukkan konsumsi pakan lebih tinggi (347,38 g/ekor/hari) dibandingkan dengan perlakuan P3 $(285,67 \mathrm{~g} / \mathrm{ekor} / \mathrm{hari})$ dan perlakuan P1(316,12 g/ekor/hari). Hal ini sejalan dengan pendapat Suparjo dkk. (2011), bahwa pakan yang berkualitas baik tingkat konsumsinya lebih tinggi dibandingkan dengan pakan yang berkualitas rendah, jika kualitasnya relatif sama maka tingkat konsumsinya juga relatif sama. Tingkat konsumsi pakan sangat berhubungan dengan bobot badan dan umur ternak. Pada perlakuan P2 (KBKFbioplus) mempunyai bobot badan yang lebih tinggi $(22,3 \mathrm{~kg})$ dibandingkan dengan bobot badan kambing pada perlakuan P3 (KBKSBP) sebesar 21,00 kg dan bobot badan kambing pada perlakuan P1 (KBKFTF) sebesar 21,30 kg. Tillman dkk. (1991) menyatakan bahwa jumlah konsumsi bahan kering ransum dipengaruhi oleh palatabilitas dan perlaluan makanan dalam saluran pencernaan. Makin banyak zat makanan yang dapat dicerna melalui saluran pencernaan berarti mengakibatkan aliran makanan semakin cepat pula, sehingga banyak ruang yang tersedia untuk penambahan makanan yang mengakibatkan ternak sanggup mengkonsumsi lebih banyak bahan kering pakan.

\section{Konversi pakan}

Konversi ransum memiliki arti penting dalam proses produksi ternak, dan sering dijadikan sebagai dasar untuk mengambil keputusan. Hasil analisis varian menunujukkan bahwa jenis fermentor tidak berpengaruh nyata $(\mathrm{P}<0,05)$ terhadap konversi pakan kambing lokal jantan yang digemukkan secara feddloting. Hasil penelitian (tabel 1) menunjukkan bahwa rata-rata konversi pakan berkisar 5,67-6,35. Hal ini berarti bahwa dipelukan pakan sekitar 5 -7 $\mathrm{kg}$ 
pakan untuk menaikan $1 \mathrm{~kg}$ bobot badan. Hasil penelitin ini menunjukkan bahwa penggunaan pakan tersebut cukup efisien. Hasil penelitian menunjukkan bahwa PBBh yang lebih tinggi terjadi pada perlakuan P2 (KBKFBioplus) yang diikuti oleh peningkatan konsumsi bahan kering pakan dengan nilai konversi pakan sebesar 5,92 serta tidak berbeda nyata $(\mathrm{P}>0,05)$ dengan konversi pakan perlakuan P1 $(6,35)$ dan perlakuan P3 $(5,67)$. Semakin kecil nilai konversi pakan maka semakin efisien ternak tersebut dalam mengkonversikan pakan ke dalam bentuk daging (Husmaini, 2000).

\section{Karateristik fisik daging kambing lokal jantan}

Rata-rata karateristik fisik daging kambing lokal jantan dengan pemberian pakan berbasis kulit kakao fermentasi disajikan pada tabel 2.

Tabel 2. Karateristik fisik daging Kambing Lokal Jantan dengan pemberian pakan berbasis kulit buah kakao (KBK) fermentasi.

\begin{tabular}{ccccc}
\hline Sifat Fisik Daging & \multicolumn{4}{c}{ Perlakuan } \\
\cline { 2 - 5 } & P1 (KBKFTF) & P2(KBKFBioplus) & P3 (KBKFSBP) & P \\
\hline DIA (\%) & $36,43 \pm 3,73$ & $36,97 \pm 4,31$ & $35,86 \pm 4,61$ & NS \\
Susut Masak (\%) & $28,00 \pm 2,65$ & $29,33 \pm 6.35$ & $30,00 \pm 4,36$ & NS \\
pH & $5,30 \pm 0,10$ & $5,13 \pm 0.06$ & $5,37 \pm 0.06$ & NS \\
Keempukan (Kg/cm) & $1,97 \pm 0,58^{\mathrm{b}}$ & $2,04 \pm 0,50^{\mathrm{a}}$ & $1,74 \pm 1,26^{\mathrm{b}}$ & $*$ \\
\hline
\end{tabular}

Keterangan : * Berbeda nyata $(\mathrm{P}<0,05), \mathrm{NS}=$ Non Signifikan $(\mathrm{P}>0,05)$

Hasil analisa varian menunjukkan bahwa jenis fermentor tidak berpengaruh nyata $(\mathrm{P}>0,05)$ terhadap sifat fisik daging kambing lokal jantan (DIA, susut masak, dan $\mathrm{pH})$, tetapi berpengaruh nyata $(\mathrm{P}<0,05)$ terhadap keempukan daging. Dari tabel 2 terlihat bahwa secara rata-rata DIA daging kambing lokal jantan berdasarkan perlakuan pakan berkisar 35,85-36,97\%, Susut masak 28,00-30,00\%, pH 5,13-5,37 serta keempukan daging 1,74-2,04 kg/ $\mathrm{cm}^{2}$. Hasil penelitian ini sejalan dengan Shanks et al. (2002) yang dikutip oleh Komariah dkk.(2009) yang menyatakan bahwa persentase susut masak berhubungan erat dengan daya mengikat air. Jika daya mengikat air rendah maka susut masak akan tinggi. Selanjutnya dikatakan bahwa daging dengan daya mengikat air rendah akan mengeluarkan banyak air ketika daging dimasak akibat kerusakan membrane seluler dan degradasi protein. Hasil penelitian ini menunjukkan bahwa daging yang memiliki DIA tinggi pada P2 (KBKFbioplus) sebesar $36,97 \pm 4,31$ memberikan susut masak daging yang rendah $(29,33 \%)$ sebaliknya daging yang memiliki DIA yang rendah seperti pada P3 (KBKFSBP) yaitu sebesar $35,86 \%$ menghasilkan susut masak yang lebih tinggi (35,86\%). Soeparno (1992) menyatakan bahwa daging yang mempunyai DIA tinggi, maka susut masak daging menjadi rendah.

Keempukan daging merupakan salah satu sifat fisik daging yang menentukan tingkat palatabilitas daging. Semakin empuk daging semakin disukai oleh konsumen. Tingkat keempukan daging ditentukan oleh beberapa faktor antara lain umur potong ternak, jenis kelamin, kandungan nutrisi pakan, bangsa sapi dan perlakuan sapi sebelum pemotongan. Hasil penelitian tentang keempukan daging kambing jantan umur potong 9-12 bulan yang diberi pakan berbasis KBK fermentasi berkisar 1,74-2,04 $\mathrm{kg} / \mathrm{cm}^{2}$. Berdasarkan pada standar tingkat keempukan daging:1-2 $\mathrm{kg} / \mathrm{cm}^{2}$ tergolong sangat empuk, $3-5 \mathrm{~kg} / \mathrm{cm}^{2}$ tergolong empuk dan lebih dari $5 \mathrm{~kg} / \mathrm{cm}^{2}$ tergolong daging keras (Wheeler et al. 2003 dalam Komariah dkk., 2009). Berpedoman dengan standar tingkat keempukan ini 
maka tingkat keempukan daging kambing lokal jantan berdasarkan perlakuan tergolong daging yang sangat empuk.

Kisaran nilai $\mathrm{pH}$ daging (tabel 2) kambing lokal jantan berdasarkan perlakuan pakan yaitu berkisar 5,13 - 5,37. $\mathrm{pH}$ daging ini masih berada pada kisaran normal $\mathrm{pH}$ daging berdasarkan titk isoelektrik yang menandakan proses regormortis telah selesai yaitu pad $\mathrm{pH} \quad 5,4$ - 5,8. Tidak terdapat perbedaan $\mathrm{pH}$ daging kambing antara perlakuan disebabkan oleh beberapa faktor antara lain: umur potong dan jenis kelamin kambing sama serta perlakuan ternak sebelum dipotong sama yaitu dipuasakan sebelum dipotong selama 12 jam sehingga ternak tidak mengalami stres, dan pada akhirnya cadangan glikogen setelah ternak mati masih tersedia dan proses regormortis sempurna. Nilai $\mathrm{pH}$ daging hasil penelitian ini sesuai dengan hasil penelitian Karda dkk.(2014) yaitu sebesar 5,6.

\section{Karateristik kimia daging kambing lokal jantan}

Rata-rata karateristik kimia daging kambing lokal jantan dengan pemberian pakan berbasis kulit kakao fermentasi disajikan pada tabel 3. Hasil analisa varian menunjukkan bahwa jenis fermentor tidak berpengaruh nyata $(\mathrm{P}>0,05)$ terhadap kadar air, protein, abu dan lemak daging kambing lokal jantan Dari Tabel 3 terlihat bahwa secara rata-rata kadar Air daging kambing lokal jantan berdasarkan perlakuan berkisar 75,105-77,065\%, kadar protein 22,760-23,600\%, Kadar Abu 0,959-1,119 dan kadar lemak 0,050$0,110 \%$.

Kadar air daging merupakan kompnen kimia daging yang proporsinya lebih tinggi dibandingkan dengan komponen kimia lainya seperti protein, lemak dan kadar abu. Kadar air daging dipengaruhi oleh jenis ternak, umur, jenis kelamin, pakan serta lokasi dan fungsi bagian-bagian otot dalam tubuh (Soeparno, 2009).

Tabel 3. Karateristik kimia daging Kambing Lokal Jantan dengan pemberian pakan berbasis kulit buah kakao (KBK) fermentasi.

\begin{tabular}{lcccc}
\hline \multicolumn{1}{c}{ Komposisi } & \multicolumn{3}{c}{ Perlakuan } & \multirow{2}{*}{ P } \\
\cline { 2 - 4 } Kimia Daging & P1 (KBKFTF) & P2(KBKFBioplus) & P3 (KBKFSBP) & \\
\hline Kadar Air (\%) & $75,105 \pm 0,061$ & $75,541 \pm 0,012$ & $77,065 \pm 0,032$ & NS \\
Kadar Protein (\%) & $23,600 \pm 0,121$ & $23,314 \pm 0,083$ & $22,760 \pm 0,144$ & NS \\
Kadar Abu (\%) & $1,119 \pm 0,49$ & $1,022 \pm 0,037$ & $0,959 \pm 0,104$ & NS \\
Kadar Lemak (\%) & $0,862 \pm 0,140$ & $0,550 \pm 0,020$ & $0,610 \pm 0,08$ & NS \\
\hline
\end{tabular}

Keterangan : NS = Non Signifikan.

Kadar air daging yang tinggi disebabkan oleh umur ternak yang masih muda, karena pembentukan protein dan lemak daging belum sempurna (Rosyidi dan Santoso, 2000). Nilai protein daging kambing lokal jantan yang diperoleh dalam penelitian ini masih berada pada kisaran protein normal daging, karena menurut Soeparno (2009) bahwa daging secara umum memiliki kisaran protein normal yaitu $16-22 \%$. Kandungan protein daging yang paling tinggi diperoleh pada perlakuan P1 $(23,600 \%)$, baru diikuti pada perlakuan P2 $(23,314 \%)$ dan yang paling rendah pada perlakuan P3 $(22,760 \%)$.

Kadar abu daging dalam penelitian ini yang paling tinggi diperoleh pada perlakuan $\mathrm{P} 1(1,681 \pm 0,515 \%)$, diikuti oleh perlakuan P2 (1,022\%), dan yang terendah pada perlakuan P3 (0,959\%). Soeparno 
(2011) menyatakan bahwa kadar abu daging sapi yang normal bisa mencapai $1,30 \%$ (otot $\mathrm{BF}$ ) dan $1,44 \%$ (otot $\mathrm{LD}$ ). Berdasarkan kisaran kadar abu daging sapi yang normal dapat dikatakan bahwa kadar abu daging hasil penelitian ini tergolong normal.

Kadar lemak daging kambing jantan lokal berdasarkan perlakuan pakan berkisar 0,050-0,110\%. Kisaran kadar lemak ini masih berada dibawah standar maksimal kadar lemak daging yang direkomendasikan sampai 13\% (Soeparno, 2009). Hasil penelitian Uyun (2008) diperoleh bahwa rata-rata kadar lemak daging kambing peranakan Boer kastrasi sebesar $8,981 \%$ sedangkan daging kambing peranakan Etawa sebesar 8,358\%. Kadar lemak hasil penelitian ini tergolong sangat rendah, hal ini disebabkan karena kambing lokal jantan dipotong pada umur yang masih muda. Soeparno (2009) menyatakan ternak yang masih muda belum mengalami pertumbuhan lemak secara maksimal. Jaringan tubuh yang berkembang pada ternak muda adalah jaringan tulang dan otot baru dikuti oleh pembentukan lemak. Kandungan lemak daging berkorelasi negatif dengan kadar air daging, semakin tinggi kandungan lemaknya maka semakin rendah kadar air daging (Soeparno, 2009). Selanjutnya dikatakan bahwa bangsa, umur, spesies, lokasi otot dan pakan merupakan factor yang dapat mempengaruhi kadar lemak daging.

\section{SIMPULAN DAN SARAN}

\section{Kesimpulan}

1. Jenis fermentor berpengaruh nyata $(\mathrm{P}<0,05)$ terhadap $\mathrm{PPBh}$, konsumsi pakan dan keempukan daging kambing lokal jantan, sedangkan terhadap daya ikat air (DIA), susut masak, $\mathrm{pH}$ dan komposisi kimia daging tidak berpengaruh nyata $(\mathrm{P}>0,05)$.

2. Kambing pada perlakuan P2 memberikan PBBh sebesar $58,67 \pm 21,590 \mathrm{~g} / \mathrm{ekor} /$ hari dan berbeda nyata $(\mathrm{P}>0,05)$ dengan $\mathrm{PBBh}$ kambing pada perlakuan $\mathrm{P} 1(49,75 \pm 18,557$ g/ekor/hari) dan perlakuan P3 (50,35 $\pm 19,606 \mathrm{~g} / \mathrm{ekor} / \mathrm{hari})$.

3. Keempukan daging kambing lokal jantan dengan pemberian pakan kulit buah kakao fermentasi tergolong sangat empuk dengan tingkat keempukan berkisar 1,74 $\pm 1,26$ $2,04 \pm 0,50 \mathrm{~kg} / \mathrm{cm} 2$.

4. Kadar protein daging kambing lokal jantan dengan pemberian pakan kulit buah kakao fermentasi berkisar $22,760 \pm 0,144-23,600 \pm 0,121 \%$ dengan kadar lemak berkisar $0,550 \pm 0,020$ $0,862 \pm 0,140 \%$.

\section{Saran}

Dalam upaya untuk mendapatkan performan, karakteristik fisik dan kimia daging kambing lokal jantan yang berkualitas sebaiknya kambing tersebut diberi pakan kulit buah kakao yang difermentasikan dengan fermentor bioplus $30 \%$.

\section{DAFTAR PUSTAKA}

Abadi T., C.M.S. Lestari an E. Purbowati, 2015. Pola Pertumbuhan Bobot Badan Kambing Kacang Betina Di Kabupaten Grobogan. Animal Agriculture Journal 4(1): 93-97.

Anas, S., A. Zubair, D., Rohmadi, 2011. Kajian Pemberian Pakan Kulit Kakao Fermentasi Terhadap Pertumbuhan Kambing. Jurnal Agrisistem. Badan Pengkajian Teknologi Pertanian (BPTP) Gorontalo.

Bulkaini, 1985. Pengaruh Umur dan Kondisi Tubuh Terhadap Pesersentase Berat Komposisi Karkas dan Kulit Segar Kambing Lokal Jantan yang Dipotong di Masbagik Lombok Timur. Skripsi. Fakultas Peternakan Universitas Mataram. 
Hasnudi, Yunilas dan F. Marbun, 2006. Pemanfaatan Hasil Sampingan Perkebunan Sebagai Pakan Tambahan bagi Kambing Kacang terhadap Karkas serta Perbandingan Daging dan Tulang Selama Penggemukan. J. Agribisnis Peternakan, Vol. 2. No. $2: 49-55$.

Herman R., 1984. Produksi daging dan Sifat Karkas Kambing Kacang. Prosiding Pertemuan Ilmiah Ruminansia Kecil. Bogor.

Husmaini, 2000. Pengaruh peningkatan level protein dan energi ransum saat refeeding terhadap performans ayam buras. Jurnal Peternakan dan Lingkungan. Vol.6(01): 6-10.

Karda I.W., 2011. Pelatihan Pembuatan Pakan Ternak dari Jerami Padi, Laporan Akhir Pengabdian Kepada Masyarakat. Pusat Penelitian Agribisnis Universitas Mataram kerjasama dengan PT. Newmont Nusa Tenggara.

Kamilidin, A. Agus dan I.G. Suparta Budisatria, 2012. Ferforman Domba yang Diberi Pakan Complete Feed Kulit Buah KakaoTerfermentasi. Buletin Peternakan. Fakultas Peternakan Universitas Gadjah Mada. Yogyakarta. Vol.36:162-168.

Kurniansyah, Aziz, R. Nugraha, dan W. A. Handoko, 2011. Fermentasi Limbah Kulit Buah Kakao Sebagai Sumber Protein Alternatif Dalam Pakan Ikan. Institut Pertanian Bogor.

Komansilan S., 2015. Pengaruh Penggunaan Beberapa Jenis Filler Terhadap Sifat Fisik Chicken Nugget Ayam Petelur Afkir. Jurnal Zootek 35 (1): 106-116.
Komariah, Sri Rahayu, dan Sarjito, 2009. Sifat Fisik Daging Sapi, Kerbau Dan Domba Pada Lama Postmortem Yang Berbeda. Buletin Peternakan UGM.Vol. 33(3): 183-189.

Laconi, E.B., 1998. Peningkatan Kualitas Kakao Melalui Amoniasi dengan Urea dan Beofermentasi dengan Phanerochaete chrysosporium serta Penye-barannya Dalam Formulasi Ransum Ruminansia. Disertasi. Program Pascasarjana Institut Pertanian Bogor, Bogor.

Murni, R., Akmal dan Y. Okrisandi, 2012. Pemanfaatan Kulit Kakao yang Difermentasi dengan Kapang Phanerochaete chrysosporium Sebagai Pengganti Hijauan Dalam Ransum Ternak Kambing.Jurnal Nutrisi dan Makanan Ternak Fakultas Peternakan Universitas Jambi.02(1):6-10.

Ngadiyono, N., dan E. Baliarti, 2001. Laju Pertumbuhan dan Produksi Karkas Kambing Peranakan Ongole Jantan dengan Penambahan Probiotik Starbio pada Pakannya. Media Peternakan 24(2):63-67.

Parwati, I.A., N.Y.M., Suyasa, S. Guntoro dan M.D. Rai Yasa, 1999. Pengaruh Pemberian Probiotok dan Laser Punkur dalam Meningkatkan Berat Badan sapi Bali.Seminar Nasional Peternakan dan Veteriner Bogor, 18-19 Oktober 1999. Puslitbang Peternakan Bogor.

Prihardono, R., 2001. Pengaruh Suplementasi Probiotik Bioplus, Lizinat Zn, Minyak Ikan Lemru Terhadap Tingkat Penggunaan Pakan dan Produk Fermentasi Rumen Domba. Skripsi. Jurusan Ilmu Nutrisi dan Makanan Ternak, Fakultas Peternakan Institut Pertanian Bogor. Bogor 
Rosyidi, D., Ardhana, M dan Santoso,

R.D., 2000. Kualitas Daging

Domba Ekor Gemuk (DEG) Betina

Periode Lepas Sapih dengan

Perlakuan Dockingdan Tingkat

Pemberian Konsentrat ditinjau dari

Kadar Air, Kadar Lemak dan

Kadar Protein.Jurnal Ilmu-ilmu

Peternakan.Vol.11 No. 3:39-44.

Sofiana, 2012. Penambahan Tepung Protein Kedelai Sebagai Pengikat Pada Sosis Sapi . Jurnal Ilmiah Ilmu-Ilmu Peternakan 15(1): 1-7.

Steel, R.G., D. J.H. Torrie, 2010. Prinsip dan Prosedur Statistika, Suatu Pendekatan Biometrik, Edisi ke 5. Penetbit PT. Gamedia Pustaka Utama, Jakarta

Soeparno, 2005. Ilmu Dan Teknologi Daging, Cetakan Keempat. Gadjah Mada.

Suparjo, K, G. Wiryawan, E.B. Laconi dan D. Mangunwidjaja, 2011. Performan Kambing yang Diberi Pakan Kulit Buah Kakao Terfermentasi. J. Media Peternakan, Edisi April 2011:2541.

Suparman, H. Hafid, L. Baa, 2016. Kajian Pertumbuhan Dan Produksi Kambing Peranakan Ettawa Jantan Yang Diberi Pakan Berbeda, JITRO VOL.3(3):1-9

Tillman, A. D., H. Hartadi, S. Reksohadiprodjo, S. Prawirokusumo dan S. Lebdosoekodjo, 1991. Ilmu Makanan Ternak Dasar. Gadjah Mada University Press. Yogyakarta.

Uyun, N., 2008. Kualitas Kimia Daging Kambing Peranakan Etawah (PE) Jantan dan Kambing Peranakan Boer (PB) Kastrasi. Jurnal Ilmu dan Teknologi Hasil Ternak. Malang. Vol.4 No. 2:9-16.
Wardojo, 1993. Agroindustri Sapi Potong. PT. Insanmitra Satya Mandiri, Jakarta. 